\title{
Chinese Cultural Implications for ERP Implementation
}

\author{
Mukesh Srivastava (I), Betsy J. Gips (2)
}

\begin{abstract}
Implementation of an enterprise resource planning (ERP) system in a global environment can be fragmented due to the internal enterprise culture, which is representative of societal culture. In China, this is especially true due to the nationalistic culture of business. The way ERP systems are perceived, treated, and integrated within the business plays a critical role in the success or failure of the implementation. When a Western developed ERP system is implemented in a country where the culture differs greatly from that of the developer, implementation may require localization in order to be successful. In doing so, strategic benefits of ERP systems may be diminished. This research paper looks into the characteristics of Chinese localization by Western vendors and the implications to the Chinese enterprise.
\end{abstract}

Keywords: Chinese Cultural Implications, Societal Culture, Strategy, ERP

(I) Assistant Professor of Computer Information Systems. College of Graduate and Professional Studies. University of Mary Washington. Fredericksburg,VS 22408

(2) College of Graduate and Professional Studies. University of Mary Washington. Fredericksburg,VS 22408 


\section{Introduction}

New brain research has found that culture can affect not just customs and language, but how people look at the world on a basic level (Goldberg, 2008). Researchers found that in Western culture, people think of themselves as highly independent. When looking at a scenic view, Westerners tend to focus on the central object more than the surrounding area. In contrast, East Asian cultures stress interdependence. When Easterners look at a picture, they tend to focus on the entire scene and the central object as just part of the scene. Implementing an Enterprise Resource Planning (ERP) system is a major cultural change for any organization. When national or cultural borders are crossed, implementation in a global environment takes on a new dimension.

While the Internet has shrunken the world to the point where we can reach out and virtually touch someone across the globe, there are great gaps in awareness. Culture, that which distinguishes one group from another, is not necessarily tangible but rather inferable from verbal statements and behaviors (Hofstede, 1993). Countries with long histories of highly traditional culture tend to have societal culture embedded in the modern organizational culture, which impacts business decision-making. An example of this is the German automaker Volkswagen, which has an ever-present nationalist culture that lies at the heart of the company's failure in the U.S. automobile market (less than five percent of the market share), yet has held the number one automaker position in Europe for decades (Keller, 1993). If culture can indeed impact a mature automobile industry, can it have a similar impact in the rapidly changing technology sector? In particular can enterprise information systems, and specifically, enterprise resource planning systems designed predominantly by Western vendors and modeled on Western business values be implemented successfully in Eastern cultures like China?

This paper is a comparative study of success factors for ERP implementation in a Chinese cultural context given Western and Asia-Pacific ERP vendors. It will attempt to answer the following research question:

$R Q_{\mid}$: Does successful ERP implementation in China require localization?

\section{Research Method}

This research paper is a result of a literature review of case studies, professional journals, news articles, and industry web sites concerning ERP implementation in general and China specifically. In some case studies, a comparison was made between advanced countries, which included the United States,
Canada, United Kingdom, Australia, Japan, and Sweden, and developing countries like China. Literature examined also included general success and failure factors in SAP ERP implementation, control and coordination in global ERP configurations, and the impact of national culture on ERP implementation and management theories.

\section{ERP Implementation}

Information technology has been a force multiplier for organizations desirous of gaining a competitive edge in a global business environment. The need to share large quantities of data effectively and efficiently between suppliers, customers, geographically dispersed units, and internal functional departments necessitated the development of integrated information systems (Monk \&Wagner, 2009, p. 4). Enterprise resource planning (ERP) systems are examples of the most strategic tools a business can employ. They help integrate company operations by creating a computing environment that includes a central database for sales and marketing, production and materials management, accounting and finance, and human resource functional business data (Monk \& Wagner, p. 27). The functional areas are further divided into modules that comprise the integrated information system environment to meet the demands of the company's strategic objectives and goals.

Strategically, implementing an ERP system facilitates better planning by management, improves management control, and increases organizational ability to control day-to-day operations. This enables the company to directly reduce operating costs and lower inventory stock while strengthening relations with suppliers and customers. Additional strategic benefits are listed in Table I. According to CIO Magazine, there are five main reasons companies implement ERP systems: integrate financial information, integrate customer order information, standardize and speed up manufacturing processes, reduce inventory, and standardize human resource information (Wailgum, 2008).

In response to a changing global marketplace, most Fortune 500 companies have implemented ERP systems over the last 10 years and reaped strategic benefits (Monk \& Wagner, 2009, p. 32). ERP eased global integration of subsidiaries and foreign business partners by integrating data across international borders. German-owned SAPAG was one of the early ERP leaders in the software industry and today boasts nearly 50,000 customers with the goal of reaching 100,000 by 2010 (Frederico, 2006). SAP is the world's leader in ERP implementation, followed closely by U.S.-owned Oracle.

Before implementing an ERP system, business enterprises analyze organizational strategy, structure, culture, and operations. Making an organization and ERP system compatible may require 


\begin{tabular}{|l|}
\hline Strategic ERP Benefits \\
\hline Accurate and Timely Information \\
\hline Real Time Data \\
\hline More Efficient Decision-making \\
\hline Global Reach \\
\hline Competitive Advantage \\
\hline Value-Rich Information \\
\hline Cross-Functional Linkage \\
\hline Business Unit Integration \\
\hline Access and Control over Daily Operations \\
\hline Agile and Adaptive \\
\hline Process Large Quantities of Information \\
\hline Eliminate Redundancy \\
\hline
\end{tabular}

Table I. ERP Strategic Benefits

the organization to change some or all of the aforementioned facets of the business. In other words, a business may need to change the way they do business in order to successfully implement an ERP system. This drives change to business process, which means people must also change. If change management is not handled well, ERP projects are apt to fail. In fact, most ERP failures on blamed on people issues rather than technology issues (Dunn, Cherrington, \& Hollander, 2005, p. 9).

The change component of ERP implementation takes on a new challenge when implementing a Western-style value proposi- tion, operating model, business process design, and supply chain integration model in China (Deng, 2005). Numerous, predominantly Western, enterprise resource planning (ERP) system vendors participate in the Chinese marketplace, but local Chinese vendors dominated the market in 2005 (Table 2). This speaks volumes about the role culture plays in ERP implementation given Western ERP vendor product maturity far exceeds that of the local vendors (Zhou-Sivunen, 2005). By 2007, China's top three domestic ERP vendors were Inspur, UFIDA, and Kingdee (Jing, 2007), with SAP taking the lead for foreign vendors.

\begin{tabular}{|l|r|}
\hline \multicolumn{2}{|c|}{2005 Top ERP Vendors in China } \\
\hline VENDOR & $\begin{array}{l}\text { NUMBER OF } \\
\text { CUST OMERS }\end{array}$ \\
\hline Ufida (China) & 40,000 \\
\hline Kingdee (China) & 23,000 \\
\hline Digital China (China) & 1,200 \\
\hline SAP (Germany) & 1,000 \\
\hline Softbrands, Inc. & 462 \\
\hline Oracle & 450 \\
\hline QAD & 350 \\
\hline SSA Global & 340 \\
\hline Epicor & 270 \\
\hline Infor & 265 \\
\hline Micros oft & 200 \\
\hline IFS & 107 \\
\hline Intentia & 50 \\
\hline
\end{tabular}

Table 2. T op EPR V endors in China (S ource: AMR Research, 2005)

*Accuired by Law son Apr 06

**Acquired by Infor May 06

N ote: All vendors U.S. businesses unless otherwise noted 
A common theme preventing more successful ERP implementations in China by Western vendors seems to be a lack of localization (Deng). Localization is defined as "Customizing software and documentation for a particular country. It includes the translation of menus and messages into the native spoken language as well as changes in the user interface to accommodate different alphabets and culture" (TE, 2008). But localization in China means much more. Localization results in customization or adaptation of the ERP system to the local Chinese enterprise culture, which can result in a loss of some or the entire strategic value proposition offered by ERP system. Given the complexity and high cost of ERP implementation, many Chinese businesses require extensive localization.

Many organizations have been guilty of taking a simplistic view on how ERP implementation will affect the culture of the organization. In fact, implementing an enterprise resource planning system forces organizational cultural transformation on many levels. Or does it? In China, if an organization changes minor processes and perhaps some operations, and does not change the business culture or strategy when implementing an information system designed by an ERP vendor, has the system really achieved enterprise integration to strategic advantage? A review of literature provided insight into ERP implementation challenges in Chinese business ventures and the connotation of culture in the success or failure of the system.

\section{Results of Literature Review}

ERP implementation first occurred in China in the 1980's and companies like SAP AG have been in the market for over 10 years (Hartung, 2008). Despite this history, rolling out a global template in China can be risky as it does not take the local environment and business culture into account. Today, ERP implementation is China still faces major challenges due to China-unique cultural factors (Avison \& Malaurent, 2007). Compared to international peers, local vendors in China seem to have a distinct advantage in product localization, sales, and channel networks (Tan, 2007). Granted, they are more familiar with local user demands and the industry market. According to Zeng Liang, vice president and general manager of Kingdee Asia Pacific, which led the Chinese ERP industry in 2007, "A lot of multinationals want some balance between Western style management practices and Chinese localization features" (Tan).

The characteristics of Chinese business culture presents cultural dimensions that differ from the typical Western business culture. Trust and respect, the management culture, the change culture, and a cultural fragmentation in the marketplace all factor together to create a unique human and social aspect to suc- cessful ERP implementation in China.

\section{The Culture Dimension of Management}

Given the top ERP vendors in China are Chinese, German, and American, Geert Hofstede's theory on cultural constraints in management may help explain why German and American ERP vendor implementations lag those of local Chinese vendors. Hofstede wrote an article entitled "Cultural constraints in management theories" in which he posits the entire concept of management in business differs by nation and there is no one universal definition for management (Hofstede, 1993). His model includes five dimensions that help explain the cultural differences that are embedded in the Chinese business culture as compared to those in the U.S. or Germany:

ple

Power Distance. Degree of inequality between peo-

(2) Individualism [vs Collectivism]. Degree to which people prefer to act as individuals

(3) Masculinity [vs Femininity]. Degree to which assertiveness, performance, success, and competition prevail in business

(4) Uncertainty Avoidance. Degree to which structured over unstructured situations are preferred

(5) Long-term [vs Short-term] Orientation. Degree oriented toward future (thrift and persistence) and past/present (tradition and fulfilling social obligations)

Table 3 below is a partial excerpt from Hofstede's article that highlights that people in other countries may think, feel, and act very differently from one another when confronted with basic business problems, or in the case of ERP systems, business solutions. Of note in Table 3 are three highlighted areas where significant deviation exists in cultural dimensions amongst China's top ERP vendors (China, Germany, and the United States). According to Hofstede's study, in Chinese business, there is a high degree of inequality between people, a high degree of collectivism (low individualism), and an extremely high orientation toward thrift, persistence, tradition, and social obligations. The table clearly shows how this contrasts with U.S. and German businesses in the same dimensions. Hofstede went on to state, Chinese businesses are typically small, have centralized decision-making by one dominate family relation, are low profile, cost conscience, loyalty to family is above all, and employees are personal relations that can be trusted. 


\begin{tabular}{|c|c|c|c|c|c|}
\hline \multicolumn{6}{|c|}{ Cultural Dimension Scores } \\
\hline & PD & ID & MA & UA & LT \\
\hline USA & $40 \mathrm{~L}$ & $91 \mathrm{H}$ & $62 \mathrm{H}$ & $46 \mathrm{~L}$ & $29 \mathrm{~L}$ \\
\hline Germany & $35 \mathrm{~L}$ & $67 \mathrm{H}$ & $66 \mathrm{H}$ & $65 \mathrm{M}$ & $31 \mathrm{M}$ \\
\hline China & $80 \mathrm{H}$ & $20 \mathrm{~L}$ & $50 \mathrm{M}$ & $60 \mathrm{M}$ & $118 \mathrm{H}$ \\
\hline \multicolumn{2}{|c|}{$\begin{array}{c}\mathrm{PD}=\text { Power Distance } \\
\mathrm{D}=\text { Individualism } \\
\mathrm{MA}=\text { Masculinity } \\
\mathrm{UA}=\text { Uncertainty Avoidance } \\
\mathrm{LT}=\text { Long Term Orientation }\end{array}$} & \multicolumn{4}{|c|}{$\begin{array}{l}\text { Among } 53 \text { countries and regions for } 1 \text { st } 4 \\
\text { dimensions and } 23 \text { countries for the } 5 \text { th: } \\
\qquad \begin{array}{c}H=\text { top third } \\
M=\text { medium third } \\
L=\text { bottom third }\end{array}\end{array}$} \\
\hline
\end{tabular}

Table 3. Hofstede's Cultural Dimension Scores (Hofstede, 1993)

Trust and Respect ("Face")

One of the six elements of Chinese culture is a personal relationship between two people referred to as guanxi (pronounced guan-shee). This dictates what you can expect from someone and what they can expect from you (FI, 2005). This connection has wide cultural implications in society and business when it comes to developing trusting relationships with business partners. A French firm experienced first hand the cultural complications through a mostly unsuccessful implementation of an ERP project at one of its Chinese subsidiaries in the international energy sector. In this case study, the authors noted Patrick Besson, European School of Management, argued that professional cultural differences can create conflict in the form of distrust of overseas vendors (Avison \& Malaurent). This arose in part because IT-enabled strategic change conflicts directly with fundamental Chinese values, which are based on "respect for hierarchical authority and equilibrium (harmony) with the system" (Avison \& Malaurent), a carryover from societal cultural values in Confucianism. This study noted that differences in culture between Western businesses that develop ERP systems and Chinese businesses are an important factor in success or failure. In fact, the name of the company was withheld from the study in order to maintain mianxi or "face" for the Chinese subsidiary in light of the unsuccessful implementation (to be criticized in public is the worst humiliation) (FI, 2005). It is important to recall ERP implementation, successful or failed, requires business process reengineering, which could give management the impression there was something wrong with current processes.

Other cultural factors caused the French/Chinese project to be deemed unsuccessful. First, Chinese businesses, being frugal, typically do not lay out large amounts of investment for IT projects (Avison \& Malaurent, 2007). The fact this project was seen as an IT venture versus a strategic investment in company value was indicative of another major difference between Western and Chinese business cultures. This point was seen again in an ERP case study of a Chinese electronics manufacturer that regarded ERP implementation as an IT-based project. It too was initially unsuccessful because the [Western] consultants hired first did not understand the "Chinese management style...interdependent social and organizational relationships and attitudes toward organizational change... [that] limited process innovation efforts" (Woo, 2007). The consultants were replaced with a local consultant that was able to develop a trust relationship with the company and turn the project around.

\section{Management Culture}

In both Chinese projects noted above, top management took very little interest in the ERP implementation. Management attitudes and values concerning control, management, and communication hampered successful implementation (Avison \& Malaurent, 2007). There was a lack of strategic expectancy for ERP adoption and management did not see the strategic benefits. Cross-functional cooperation was lacking as many managers put the needs of their department above the needs of the enterprise (Hartung, 2008). Because the project was considered IT-related and did not have a strategic focus or sponsor in top management, the IT staff took the lead roles on the project teams (Woo, 2007). This was and is a common situation in China, and unfortunately, these individuals did not have the authority or power to affect business process changes required for proper ERP implementation.

In addition, the IT staff did not have the project management experience for a project of this magnitude. In the case of the Chinese electronics manufacturer, the IT staff was given a 2week crash course in project management, which contributed in part to turning the ERP project around (Woo). A top management project sponsor was also appointed as a symbolic gesture to explain why the company was implementing the new ERP system, communication which had been previously absent 
for employees. In fact, in Chinese business culture, management is not accustomed to explaining actions to employees so the progress of the project had not been communicated down the chain of command (Woo). The culture was such that the CEO and management tended to act as father figures to employees. This meant management was perceived to know what was best for the employees and that employees should place trust in the manager's judgment...questioning leadership was/is not done (Fl, 2005). This resulted in a workforce that did not have the "big picture" view of the organization and its goals.

\section{Change Culture}

Two main features of Chinese business culture are patience and humility (keqi). Chinese business culture views change differently than Western culture. In Western-style businesses, change management has been around since the 1980's. Students of management like Jeanenne LaMarsh, Michael Hammer, Edward Demming,William Bridges, and John Kotter aided Western business managers in understanding how the mechanical and human forces of change converge into what is now a core competency of change management for business success (Hiatt, 1996-2008). Eastern cultures like China place great value on the past and are reluctant to change, which limits process innovation (Woo, 2007). Consequently, as in the electronics manufacturer case study, the Chinese firm did not recognize the need to redesign key processes to fit the ERP implementation (Woo). Deng's AMR Research report supported this observation as he noted "most Chinese users prefer to use the system to automate current processes rather than change processes to fit in the ERP system" (Deng, 2005).

Deng's report noted other cultural barriers to change in the Chinese business place. For example, he noted that "even with ERP in place, most companies still prefer manual processes or old systems (Deng, 2005). He noted restructuring a company for ERP implementation was painful because of inflexible change management and top management preferred to keep old control methods. This often required major customization for the Western ERP vendor if the system was to fit into the Chinese business culture. In the example of the electronics manufacturer, every element of Chinese cultural characteristics, and business and management style and practice had to be taken into consideration before the project could be turned around (Woo, 2007).

\section{Cultural Fragmentation in the Marketplace}

China has one of the world's oldest peoples and continuous civilizations. Hundreds of ethnic groups exist, each with distinct cultural traditions. These cultural traditions are regionalized over 9.6 million square kilometers (CIA World Factbook,
2008). This makes for a very fragmented Chinese market. For example, business practices in Beijing differ from those in Shanghai; hence the cultural nuances in ERP implementation also differ. Mandarin is the official language and spoken by most Chinese, but language differences by region are challenging for Western ERP consulting teams (Huang \& Palvia, 200I).

Across the different groups, there was one unfortunate common denominator-the Chinese culture did not regard computers as a pervasive way of doing business (Huang \& Palvia, 200I). According to a case study in the Business Process Management Journal, they [Asian countries with large populations] prefer to "explore ways of increasing human efficiency rather than replacing humans with integrated systems" (Huang \& Palvia). Deng's research also noted ERP system "success will come by developing systems and services that meet key Chinese needs... [one need being a] system that supports rapid changes, not labor savings..." (Deng, 2005). Over the last several years, this has changed somewhat due to global pressures and the rapidly growing Chinese presence in a competitive world marketplace, but IT infrastructure is still young in China, employees are often IT-inexperienced, and readiness for change is not universally accepted across the enterprise (Gargeya \& Brady, 2005).

\section{Discussion of Results}

ERP localization in China is not only about translating menus and messages into the Chinese language. It is about adapting ERP implementation to meet the needs of the culture of the local user. Yet, localization has implications. The business cultural elements addressed in the previous section drove ERP implementation in a way that diminished the strategic value of the system. For example, in France's Chinese energy subsidiary, the pilot SAP ERP initiative was seen as a cornerstone to improving efficiency between five sales offices, a factory and four joint ventures employing 820 employees in China. The goal was to implement five modules (finance, control, sales and distribution, materials management, and project system) (Avison \& Malaurent, 2007). What happened was:

- Limited employee involvement (Management Culture/poor communication)

- Distrust of European expatriates on the implementation team (Trust/Respect)

- Legacy system was kept in place (Change Culture)

- Implementation team exposed weaknesses in Chinese managers and 'face' was lost (Trust/Respect) 
- Chinese staff adopted a passive attitude toward the project (Cultural Dimension)

Through the failed project, the authors observed the French headquarters "desire for...a global template...conflict[s] with the local conditions and...these conflicts are likely to increase from European to Asian situations where cultural differences become more and more marked" (Avison \& Malaurent, 2007). Strategic benefits were minimized.

In the case of the Chinese electronics manufacturer, cultural characteristics also led to project failure. Contributing cultural factors included:

- Lack of top management visibility (Management Culture)

- Inexperience, poorly formed project team with IT only focus (Management Culture)

- Business processes were not redesigned (Management Culture)

- Employee training program was ineffective and insufficient (Cultural Fragmentation)

- No widespread understanding or acceptance of ERP (Management Culture)

The author in this case observed "the approach used to implement ERP in the West is applicable to China if consideration is given to cultural differences..." (Woo, 2007). Again, strategic benefits were minimized.

Deng's AMR Research report "Inside the Chinese ERP Market" listed five localization recommendations for vendors attempting to enter the Chinese ERP market (2005):

- Be flexible (in product, marketing, pricing, and contracts negotiations)

- Simplify (small, easy-to-understand packages)

- Be selective (largely Chinese contracts are not profitable, so understand customer needs before contract offer)

- Collaborate (with users on implementation, post-sales services, education, and supply chain)

- Invest in R\&D (set up R\&D center in China; be closer to local culture)
Deng's research, by omission, indicated strategic benefits for ERP implementation were not foremost in Chinese management's goals for the project.

The majority of authors of reviewed literature stated Western ERP vendors needed to adapt ERP offerings to fit the Chinese organizational culture-localization. But, when compared to the value that ERP implementation should bring to an organization, implementation in China seemed to be more about automating manual processes than gaining strategic advantage. Few if any of the strategic benefits were achieved when Western ERP systems were localized to the Chinese business culture. Data was not real time if manual processes continued to be used and legacy systems were not integrated. Crossfunctional linkage was not achieved if a holistic, strategic approach was not taken by top management. Businesses did not become agile and adaptive if business processes were not reengineered. In essence, Western ERP systems, once implemented, did not resemble ERP systems at all, at least not by Western standards.

\section{Findings}

The limited literature research conducted for this paper does not conclusively lend credence to the idea that localization is required for successful ERP implementation in China. The rationale is because using ERP technology to automate manual processes, without regard for strategic transformation of the business, does not constitute implementation of an integrated information system as defined by an ERP system. Additional research done outside the China realm showed this conflict between business strategy and culture could be similarly applied to other countries where a long-standing social culture is deeply embedded in the business culture- a culture that differs in cultural dimension from the ERP developer vendor Specifically, case studies in Greece (Koh, Simpson, Padmore, Dimitriadis, \& Misopoulos, 2006), Mexico (Utecht, Hayes, \& Okonkwo, 2004), Turkey (Baki, Dereli, \& Baykasoglu, 2004), and India (Huang \& Palvia, 200I) share similar cultural implications for ERP implementation outlined in this paper.

The model in Figure I below depicts that as the ERP strategic value propositions (or strategic benefits) are gradually restricted by business culture embedded in a strong societal culture, ERP implementation benefits can be reduced to the point of near exclusion. This is symbolized by the flow of benefits through a funnel. As the funnel narrows, fewer and fewer benefits flow out the other end into the enterprise. 


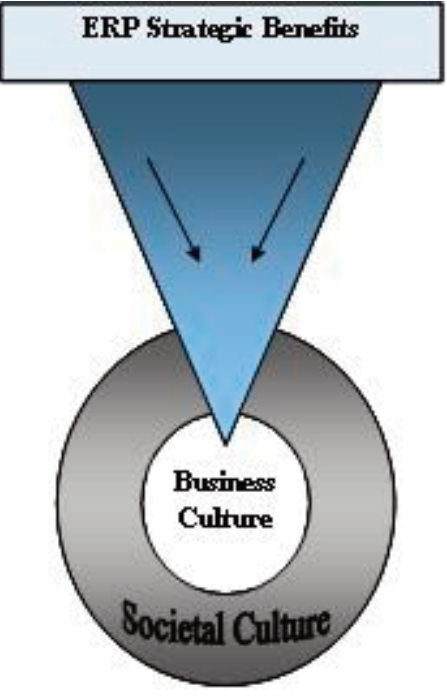

Figure I. Cultural Implications for ERPValue Proposition Model

\section{Conclusion}

Deng stated Chinese ERP systems in 2005 were similar to those in North American and Europe 10-15 years ago (Deng, 2005). Given that ERP systems have been in China since the 1980's and in the West since the MRP in the 1960's and 1970's, it may be another decade or more before Chinese business culture evolves toward implementing ERP systems than reap the full benefits of an integrated information system that empowers strategic enterprise competitive advantage. Whether ERP software changes to accommodate Chinese business culture or Chinese business culture shifts more towardWestern styles can only be concluded by future research in the area of localization of ERP systems in China. Gordon Redding, who wrote "The Spirit of Chinese Capitalism," postulated in his 1990 study that neither the "highly culture-determined" Chinese entrepreneur nor the Chinese economy will "adjust to assimilation or the forces of modernism" (Redding, 1992). Today, globalization and Chinese state capitalism combined with consumerism and nationalism will likely be drivers for change in China. Whether or not these drivers can overcome centuries of tradition and culture will be interesting to observe.

\section{References}

AVISON, D., \& Malaurent, J. (2007, October 5). Impact of cultural differences: A case study of ERP introduction in China. International Journal of Technology and Information Management, 27, pp. 368-374. Retrieved June 20, 2008, from Academic OneFile Database.
BAKI, B., Dereli, T., \& Baykasoglu, A. (2004). An investigation on the readiness of Turkish companies for enterprise resource management. Journal of Manufacturing Technology Management, 15, pp. 50-56. Retrieved June 16, 2008, from Academic OneFile Database.

CIA World Factbook (2008). . Retrieved June 29, 2008, from http://encompass.library.cornell.edu/cgi-bin/checkIP.cgi?access=gateway_standard\%26url=http://www.xreferplus.com/letter_picker.jsp?vol=554

DENG, Q. (2005, September). Inside the Chinese ERP market. Retrieved June 24, 2008, from https://www.qad.com/Public/ Documents/AMR-Inside_the_Chinese_ERP_Market.pdf

DUNN, C. L., Cherrington, J. O., \& Hollander, A. S. (2005). Enterprise information systems: A pattern-based approach (3rd ed.). New York: McGraw-Hill Irwin.

Fjell International (2005). Chinese Business Culture. Retrieved June 28, 2008, from http://www.fjell.nl/ Chinese\%20 Business\%20Culture.pdf

FREDERICO, T. M. (2006, August 8). SAG AG in 2006: Driving corporate transformation.

GARGEYA,V. B., \& Brady, C. (2005). Success and failure factors of adopting SAP in ERP system implementation. Business Process Management Journal, II, PP. 50I-516. Retrieved June 16, 2008, from Academic OneFile Database. 
GOLDBERG, C. (2008, March 3). Cultural insights: Brain scans support surprising differences in perception between Westerners and Asians. The Boston Globe. Retrieved June 22, 2008, from http://www.boston.com/news/science/articles/2008/03/03/cultural_insights/

HARTUNG (2008). ERP in China. Retrieved June 29, 2008, from http://www.hartung.com.cn/index.php?mod=specific\&type=spe c_erpinchina

HIATT,J. (1996-2008). The definition and history of change management. Retrieved June 28, 2008, from http://www.changemanagement.com/tutorial-definition-history.htm

HOFSTEDE, G. (1993, February). Cultural constraints in management theories. Academy of management executive, 7, pp. 8I-90. Retrieved June 26, 2008, from http://www.francescopignatti. com/eng/index.php?option $=$ com_vfm\&ltemid $=37 \&$ do $=$ down load\&file $=M M \%$

HUANG, Z., \& Palvia, P. (200I). ERP implementation issues in advanced and developing countries. Business Process Management Journal, 7, pp. 276-284. Retrieved June 16, 2008, from Business OneFile Database.

JING, C. (2007, September 27). Domestic ERP software gets brand recognition. Retrieved June 29, 2008, from http://en.ce.cn/Insight/200709/27/t20070927_|3062673.shtml

KELLER, M. (1993). Collision: GM, Toyota, Volkswagen and the race to own the 2 I st century. New York: Doubleday.

$\mathrm{KOH}$, S. C., Simpson, M., Padmore, J., Dimitriadis, N., \& Misopoulos, F. (2006). An exploratory study of enterprise resource planning adoption in Greek companies. Industrial Management and Data Systems Journal, 106, Pp. 1033-1059. Retrieved June 16,2008, from www.emeraldinsight.com

MONK, E., \& Wagner, B. (2009). Concepts in enterprise resource planning (3rd ed.). United States: Course Technology Cengage Learning.

On-Line Consultant Software (2008). Top ERP Vendors. Retrieved June 23, 2008, from http://www.olcsoft.com/ top\%20ERP\%20vendors.htm

REDDING, S. G. (1992, 3rd Qtr). The spirit of Chinese capitalism. Journal of International Business Studies, 23, pp. 572-574. Retrieved June 29, 2008, from http://www.jstor.org/pss/I55097
TAN, A. (2007, January 17). Kingdee wants to conquer Asia. Retrieved June 24, 2008, from http://www.zdnetasia.com/ news/software/ 0,39044I64,6198258I,00.htm

TechEncyclopedia (2008). Localization. Retrieved June 27, 2008, from http://www.techweb.com/encyclopedia/defineterm.jhtml? term=localization

UTECHT, K. M., Hayes, R. B., \& Okonkwo, P.A. (2004). ERP and the competitive advantage: the ease of integrating information between corporate headquarters in the United States and factories in Mexico. Retrieved June 16, 2008, from Academic OneFile Database.

WAILGUM, T. (2008, April). ABC: An introduction to ERP. Retrieved June 23, 2008, from http://www.cio.com/article/40323/ABC_An_Introduction_to_ERP/2

WOO, H. S. (2007). Critical success factors for implementing ERP: the case of a Chinese electronics manufacturer. Journal of Manufacturing Technology Management, I8, Issue 4, pp. 43I-442. Retrieved June 16, 2008, from Academic OneFile.

ZHOU-SIVUNEN, P. (2005). Organizational culture impact on ERP implementation in China. Swedish School of Economics and Business Administration. Retrieved June 22, 2008, from Academic OneFile Database. 